\title{
MIROBIAL PROFILE OF SOME EGYPTIAN TRADITIONAL FOODS AS
} AFFECTED BY STORAGE

\author{
Aya M.I. Farrag ${ }^{*}$, Nahed A. El-Wafai, Howaida M. Abdel-Basit and M.I. Hegazy \\ Agric. Microbiol. Dept., Fac. Agric., Zagazig Univ., Egypt
}

\begin{abstract}
The safety of ready-to-eat foods is an important topic in today's life. Improper handling of readyto-eat food items may result in foodborne outbreaks. In this study, koshari, vegetable salad and couscous were selected as the target ready-to-eat foods for a microbiological survey. The aim of this study was to evaluate the microbiological quality of koshari, vegetable salad and couscous sold in Zagazig shops in Sharkia Governorate. A total of 39 samples were collected from food stores in winter and summer seasons. They were tested for the presence of pathogenic microorganisms causing food poisoning (Salmonella spp., Shigella spp., enterococci and staphylococci), spoilage microorganisms (fungi and yeasts), total aerobic viable counts, lactic acid bacteria and coliform groups. The study also aimed to monitor the population changes of the previous microbial groups during the storage of these foods at refrigerator temperature $\left(5-7^{\circ} \mathrm{C}\right)$ and abuse conditions of room temperature $\left(22 \pm 2{ }^{\circ} \mathrm{C}\right)$. By comparing the three tested foods, generally vegetable salad had the highest microbial populations, followed by koshari, then couscous. The numbers of Salmonella and Shigella were 6.15, 5.47and 4.89 $\log \mathrm{cfu} / \mathrm{g}$ in summer for vegetable salad, koshari and couscous, respectively. Also, the average microbial counts in summer are clearly higher than those in winter. Generally, the microbial numbers kept increasing for several days, then started to decrease. For most microbial groups, the peak of their numbers were at days 5, 3-5 and 6-8 for koshari, vegetable salad and couscous, respectively. By looking at microbial numbers changes in vegetable salad stored in refrigerator, enterococci increased up to $2.26 \log \mathrm{cfu} / \mathrm{g}$ after 5 days, staphylococci increased up to $0.12 \log \mathrm{cfu} / \mathrm{g}$ after 1 day, coliforms increased up to $0.77 \log \mathrm{cfu} / \mathrm{g}$ after 3 days and Salmonella and Shigella increased up to $0.45 \mathrm{log} \mathrm{cfu} / \mathrm{g}$ after 2 days. All of these groups started to decrease thereafter. Based on the current results, it is higher recommended to follow routine inspections and training of vendors to improve the microbiological quality of food products.
\end{abstract}

Key words: Storage, traditional food, foodborne pathogens, koshari, vegetable salad, couscous.

\section{INTRODUCTION}

Traditional foods are considered as high-risk foods because no further treatment such as heating is required before eating. Improper handling of traditional foods may cause contaminations and display at improper temperature favours the rapid growth of pathogens and may result in foodborne outbreaks. Therefore, control of bacterial levels is critical to ensure the safety of such ready-toeat foods. Ready-to-eat (RTE) food is defined as

\footnotetext{
* Corresponding author: Tel. : +201148861326
}

E-mail address: yoyofarag@yahoo.com food that can be consumed at the point of sale without further preparation or treatment. It could be raw, partially or fully cooked and hot, chilled or frozen (FEHD, 2007; USFDA, 2009). Readyto-eat food can be animal food, plant food, fruits and vegetables, or bakery products (USFDA, 2009). Methods of processing, storage, handling and display can affect the levels of microorganisms in ready-to-eat food (Fang et al., 2003 ; Christison et al. 2008).

Foodborne disease outbreaks linked with RTE foods have been associated with various 
foodborne pathogens (Gilbreth et al., 2005; Gibbons et al., 2006). The initial microbiological load on RTE food ingredients is important, however, factors such as handling, processing, storage and display may influence the microbiological load of RTE foods at the point of sale (Beuchat and Ryu, 1997; Angelidis et al., 2006).

Human pathogens like Listeria monocytogenes, Salmonella and Escherichia coli O157-H7 may contaminate the product during plant cultivation and processing (Francis et al., 1999; Brandl, 2006; Franz and Van Bruggen, 2008). Contamination with enteric pathogens may occur through various routes, including use of organic waste as fertilizers, contamination of irrigation water with feacal material, direct contamination by livestock and wild animals, hygienic problems in handling and processing (Heaton and Jones, 2007). The significant negative relationship found between produce visual quality and the levels of total aerobic viable count, coliforms and lactic acid bacteria (LAB) confirms the association between spoilage and $\mathrm{LAB}$ levels and the statement that RTES shelf-life is largely conditioned by the microbiological and sensory quality levels at the processing factory gate (Sinigaglia et al., 1999). Enterobacteriaceae are useful indicators of hygiene and post processing contamination of heat - processed food. The bacterial counts and coliforms are indicators of sanitation and could signify unhygienic conditions during food handling and preparation. Escherichia coli is a significant diarrhoeal causing organisms usually found in localities of poor sanitary conditions Umoh and Odobab (1999). It has been associated with "travelers' diarrhoeal and hemorrhagic colitis. Therefore, consumption of this food could be associated with diarrhoeal diseases (Hanoshiro et al., 2004).

The purpose of this study is to determine the extent to which koshari, vegetable salad and couscous were contaminated with aerobic bacteria, hygiene indicator bacteria, potential foodborne pathogen, yeast and fungi at the point of sale in Sharkia Governorate. In addition, the effect of different storage temperatures on the presence of aforementioned microorganisms was investigated.

\section{MATERIALS AND METHODS}

\section{Food Sampling Procedures}

In this study, traditional food products were obtained from shops, Sharkia Governorate, Egypt. A total of 39 samples of three traditional food products, i.e. koshari; vegetable salad and couscous were randomly colected from June to September in 2012 and December to March in 2013. These samples were transported in an ice box to the laboratory of Agricultural Microbiology Department, Faculty of Agriculture, Zagazig University, Egypt for microbiological analyses.

\section{Microbiological Analyses}

Ten grams of each of koshari, vegetable salad and couscous were separately transferred to a $250 \mathrm{ml}$ Erlynmayar flask containing $90 \mathrm{ml}$ of sterile peptone saline solution $(0.1 \%$ peptone and $0.85 \% \mathrm{NaCl}$ ) and well mixed, then serial dilutions up to $10^{7}$ were prepared. One tenth $\mathrm{ml}$ of each dilution was spred on the surface of plate count agar medium (P.C. agar, Oxide) then incubated at $30 \pm 2^{\circ} \mathrm{C}$ for $48 \mathrm{hr}$., for enumeration the total bacterial count (Hausler, 1972). For lactic acid bacteria (LAB) enumeration, MRS agar (De-Man, Rogosa and sharp) were used for counting lactobacilli after incubation at $30^{\circ} \mathrm{C}$ for 24- 48 hr., (De-Man et al., 1960). Enterococcus was enumerated on Kanamycin Aesculin Azide - agar medium (Difco, 1989), then incubated at $37^{\circ} \mathrm{C}$ for $48 \mathrm{hr}$. Black colonies on Kanamycin Aesculin Azide-agar are typical colonies of enterococci. Staphylococcus spp. was enumerated on Baird-parker's medium (Oxide CM 275) (Baird-Parker and Davenport, 1965). The total coliforms were counted according to Harrigen and Mccance-Margart (1976) using MacConkey - agar medium. Plates were incubated at $37^{\circ} \mathrm{C}$ for $24 \mathrm{hr}$. Pink colonies on MacConkey agar are typical colonies of coliform. Salmonella and Shigella spp. were counted using S.S. agar (Oxide CM 99). All plates were incubated at $37^{\circ} \mathrm{C}$ for $24 \mathrm{hr}$., (Harrigen and Mccance-Margart, 1976). Black and pink colonies on S.S. agar are typical colonies of Salmonella spp. and Shigella spp., respectively. For yeast enumeration, yeast extract-malt extract agar (YM-agar, Kreger-van Rij, 1984) was used. Colonies were counted after incubation at $28 \pm 2^{\circ} \mathrm{C}$ for $48 \mathrm{hr}$. Moulds were enumerated by using Potato - dextrose - 
agar (PDA) medium at $28^{\circ} \mathrm{C}$ for $72 \mathrm{hr}$. The samples were tested for the presence of hazard microorganisms causing poisoning and spoilage.

\section{Storage Effect on Microbial Load}

The samples under investigation were kept at refrigerator temperature $\left(5-7^{\circ} \mathrm{C}\right)$ and sampled for microbial groups enumeration daily for up to 9 days. Other samples were kept for 36 hours at room temperature $\left(22 \pm 2^{\circ} \mathrm{C}\right)$ and sampled for enumeration at $0,12,24$ and 36 hours. Ten grams of each sample were homogenized with $90 \mathrm{ml}$ of sterile peptone saline solution and serial decimal dilutions were prepared. Appropriate dilutions were inoculated onto petri dishes of different nutrients and selective media.

\section{Statistical Analysis}

One-way analysis of variance was used to analysis the data using the General Linear Model procedure by SAS 1998 (Statistical Analysis System). Duncan's multiple range test system (1955) was used to compare the least significant difference (LSD) of treatments at $\mathrm{P}$ value of $\leq 0.05$.

\section{RESULTS AND DISCUSSION}

\section{Microbial Counts of Traditional Food Products in Sharkia Governorate (Zagazig City)}

Eight different microbial groups were enumerated in the three traditional food products (koshari, vegetable salad and couscous). Data in Table 1 show the different microbial counts in traditional foods obtained from different restaurants in Zagazig City, Sharkia Governorate in winter and summer. Each number in this table reflects the average of 6 samples enumerations bought from different stores during each season.

The average microbial counts in winter of aerobic bacteria, lactic acid bacteria, enterococci, staphylococci, coliform and Salmonella and Shigella in koshari samples were 7.04, 3.23, 4.03, 2.65, 4.56 and $4.32 \log$ cfu/g, respectively. Yeasts and fungi did not show any growth in winter. In summer, the average counts for the same eight different microbial groups in koshari samples were 7.68, 6.41, 5.50, 5.07, 6.22, 5.47, 0.43 and $0.78 \mathrm{log} \mathrm{cfu} / \mathrm{g}$, respectively. Umoh and
Odobab (1999) counted the aerobic bacteria in some Nigerian foods and found that the count in the boiled white rice was $4.14 \mathrm{log} \mathrm{cfu} / \mathrm{g}$, while the average count for two other food types (Soup and Moin-moin) was $3.62 \mathrm{log} \mathrm{cfu} / \mathrm{g}$. They also showed in their study that while rice accounted for $26.2 \%$ of the positive samples for $B$. cereus, six other foods (Fried fish, Tuwo, Soup, Kosai, Kunu and Moin-moin) accounted for $73.8 \%$ (an average of $12.3 \%$ for each one). The percentage of rice positive samples for $S$. aureus was $16.7 \%$, while the other six foods accounted for $83.8 \%$ (an average of $12.3 \%$ for each one). This result indicated that koshari is expected to have higher microbial load than other food types, especially since the other major component of Koshari is pasta, which is mainly composed of starch an easily degradable food source for microorganisms. Mensah et al. (2002) found that the mean bacterial count in macaroni samples analyzed was $5.48 \mathrm{log} \mathrm{cfu} / \mathrm{g}$. This food is often prepared by heating, but gets cold by the time it is served because the sellers are not able to keep the food at a good holding temperature and therefore ambient temperatures provide a suitable condition for the growth of microorganisms. The contamination of this food was not surprising because after cooking the food serving was performed with bare hands.

In Vegetable salad samples, the average microbial counts in winter for aerobic bacteria, lactic acid bacteria, enterococci, staphylococci, coliform and Salmonella and Shigella, yeasts and fungi were $6.58,5.89,4.58,4.25,4.40,4.37$, 1.72 and $5.33 \log \mathrm{cfu} / \mathrm{g}$, respectively. In summer, the average counts for the same eight different microbial groups in Vegetable salad samples were 8.13, 7.92, 6.77, 6.32, 6.20, 6.15, 2.01 and $5.54 \log \mathrm{cfu} / \mathrm{g}$, respectively. Microbiological surveys of retail ready to eat salad (RTES) have considered the occurrence of enteric bacterial pathogens, Escherichia coli, coliforms, total aerobic and spoilage bacteria, fungi and yeasts. Most reported counts range between 4 and $8 \mathrm{log} \mathrm{cfu} / \mathrm{g}$ for total aerobic bacteria and around $6 \mathrm{log} \mathrm{cfu} / \mathrm{g}$ for coliforms (Wojcik-Stopczynska, 2004; Tournas, 2005; Fröder et al., 2007; Pavan da Silva et al., 2007 ; Pianetti et al., 2008). These numbers are in accordance with the obtained results in the 
current study, expect for coliform count in winter (4.40 log cfu/g), which is still in

Table 1. Average of different microbial enumerations ${ }^{\mathrm{a}}(\log \mathrm{cfu} / \mathrm{g})$ for different traditional foods in winter and summer

\begin{tabular}{|c|c|c|c|c|c|c|c|c|c|}
\hline Traditional food & $\begin{array}{l}\text { Study } \\
\text { season }\end{array}$ & $\begin{array}{l}0 \\
0\end{array}$ & هِّ & 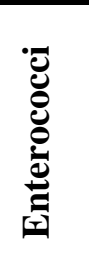 & 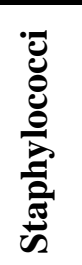 & : & 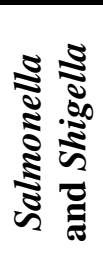 & 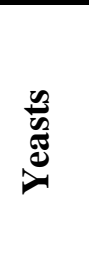 & 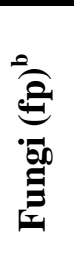 \\
\hline \multirow{2}{*}{ Koshari } & Winter & 7.04 & 3.23 & 4.03 & 2.65 & 4.56 & 4.32 & 0.00 & 0.00 \\
\hline & Summer & 7.68 & 6.41 & 5.50 & 5.07 & 6.22 & 5.47 & 0.43 & 0.78 \\
\hline \multirow{2}{*}{ Vegetable salad } & Winter & 6.58 & 5.89 & 4.58 & 4.25 & 4.40 & 4.37 & 1.72 & 5.33 \\
\hline & Summer & 8.13 & 7.92 & 6.77 & 6.32 & 6.20 & 6.15 & 2.01 & 5.54 \\
\hline \multirow{2}{*}{ Couscous } & Winter & 5.27 & 2.42 & 1.97 & 3.37 & 1.60 & 1.29 & 0.00 & 0.68 \\
\hline & Summer & 5.61 & 5.34 & 4.48 & 4.10 & 5.28 & 4.89 & 0.93 & 0.91 \\
\hline
\end{tabular}

a- Numbers (log cfu/g) are mean values of three replicates.

agreement with Gitahi et al. (2012) who found that total coliform count in vegetable salad was $4.48 \mathrm{log} \mathrm{cfu} / \mathrm{g}$. Gitahi et al. (2012) found that Staphylococcus aureus counts were $4.03 \mathrm{log}$ $\mathrm{cfu} / \mathrm{g}$ in vegetables. Higher occurrence of Staphylococcus aureus suggests a contamination which originates from food handling that might have occurred in the street foods during handling, processing or vending. Staphylococcus aureus, being a part of the microflora present on/in several parts of the human body, is a good indicator of contamination due to poor personnel hygiene practices (Nester et al. 2001).

The average microbial counts in couscous samples for aerobic bacteria, lactic acid bacteria, enterococci, staphylococci, coliform and Salmonella and Shigella and fungi in winter were $5.27,2.42,1.97,3.37,1.60,1.29$ and 0.68 $\log \mathrm{cfu} / \mathrm{g}$, respectively. Yeasts showed no growth in winter. In summer, the average counts for the same eight different microbial groups in couscous samples were 5.61, 5.34, 4.48, 4.10, 5.28, 4.89, 0.93 and $0.91 \log \mathrm{cfu} / \mathrm{g}$, respectively.

By comparing the three tested foods, generally vegetable salad had the highest microbial populations, followed by koshari then couscous. An obvious reasons for that, is the absence of heat treatment in vegetable salad preparation, which allows for microbial growth, a situation that contradicts with the preparation method of koshari and couscous. Also, the average microbial counts in summer are clearly higher than those in winter for the same food; this is most likely be due to the lower temperature in winter than in summer season.

\section{Effect of Storage at Refrigerator and Room Temperature on Microbial Load of the Tested Foods}

\section{Effect of refrigerator storage on koshari}

Data in Table 2 show the effect of refrigerator storage $\left(5-7^{\circ} \mathrm{C}\right)$ on microbial counts of koshari sample. The population of the total bacterial count showed the lowest rate of increase by only 
increasing $24.8 \%$ after four days, while yeasts showed the highest increase, reaching 522\%

after four days. Other microbial groups, i.e. lactic

Table 2. Changes in Koshari microbial popualtion ${ }^{a}$ during refrigerator storage for $\mathbf{5}$ days

\begin{tabular}{|c|c|c|c|c|c|c|c|c|}
\hline $\begin{array}{l}\text { Microbial count } \\
\text { Storage time (day) }\end{array}$ & 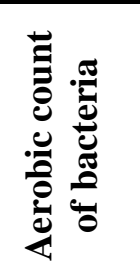 & تِ & 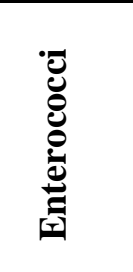 & 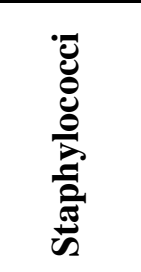 & $\stackrel{\Xi}{: 0}$ & 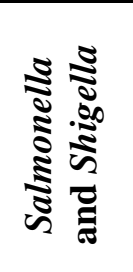 & 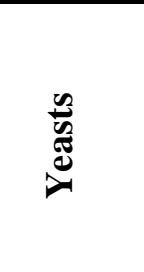 & 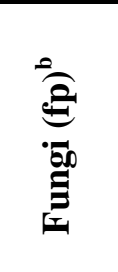 \\
\hline$\overline{\text { Zero }}$ & $7.41 \mathrm{c}$ & $6.62 \mathrm{~d}$ & $4.96 \mathrm{~d}$ & $4.02 \mathrm{~d}$ & $6.34 \mathrm{e}$ & $6.27 \mathrm{e}$ & $0.00 \mathrm{~d}$ & $0.00 \mathrm{c}$ \\
\hline 1 & $7.60 \mathrm{c}$ & $7.16 \mathrm{c}$ & $6.99 \mathrm{c}$ & 5.87 c & $7.24 \mathrm{~d}$ & $7.14 \mathrm{~d}$ & $0.00 \mathrm{~d}$ & $0.00 \mathrm{c}$ \\
\hline 2 & $8.62 \mathrm{~b}$ & $8.58 \mathrm{~b}$ & $8.03 \mathrm{~b}$ & $6.16 \mathrm{bc}$ & 8.12 c & 8.07 c & $3.70 \mathrm{c}$ & $0.00 \mathrm{c}$ \\
\hline 3 & $9.07 \mathrm{a}$ & $8.97 \mathrm{a}$ & $8.24 \mathrm{~b}$ & $6.46 \mathrm{~b}$ & $8.52 \mathrm{~b}$ & $8.61 \mathrm{~b}$ & $5.03 \mathrm{~b}$ & $0.00 \mathrm{c}$ \\
\hline 4 & $9.25 \mathrm{a}$ & $9.11 \mathrm{a}$ & $8.82 \mathrm{a}$ & $7.05 \mathrm{a}$ & $8.77 \mathrm{~b}$ & $8.88 \mathrm{~b}$ & $5.22 \mathrm{ab}$ & $3.30 \mathrm{~b}$ \\
\hline 5 & $8.91 \mathrm{ab}$ & $9.11 \mathrm{a}$ & $8.84 \mathrm{a}$ & $7.08 \mathrm{a}$ & $9.64 \mathrm{a}$ & $9.46 \mathrm{a}$ & $5.37 \mathrm{a}$ & $3.70 \mathrm{a}$ \\
\hline
\end{tabular}

a- Numbers (log cfu/g) are mean values of three replicates.

b- fp: Fungal propagules.

acid bacteria, enterococci, staphylococci, coliforms, Salmonella and Shigella and fungi showed the rate of increase by 37.6, 78.2, 76.1, 52.1, 56.9 and 370 percent, respectively, after five days. Yeasts and fungi showed the lowest numbers (no growth) at zero time, while the total count of bacteria showed the highest numbers (7.41) at zero time. These results indicated that all microbial counts, significantly increased $(\mathrm{p}<$ 0.05 ) when stored at refrigerator temperature for 5 days.

Due to the lake of available microbiological studies about Koshari, rice was used as reference in some discussions. A study on the cooked rice stored at refrigerator temperature $\left(5-7^{\circ} \mathrm{C}\right)$ for 24 hours showed no viable bacterial load, while after another 24 hours of storage, the refrigerated rice showed $6.9 \times 10^{5} \mathrm{cfu} / \mathrm{g}$ (Ali et al., 2008). According to the FAO/WHO expert consultation of microbiological specifications, a maximum of $5 \times 10^{4} \mathrm{cfu} / \mathrm{g}$ of mesophilic aerobic bacteria are safe for human consumption. Also, Frazier and Westhoff (1995) mentioned that the values at or above $10^{6}$ are unacceptable.

\section{Effect of refrigerator storage on vegetable salad}

Data in Table 3 represented the effect of refrigerator storage on microbial counts of Vegetable salad samples. Concerning, aerobic count of bacteria, data show that a significant increase was found after $24 \mathrm{hr}$., until the $3^{\text {rd }}$ day, then started to decrease thereafter. Aerobic bacteria and coliform counts showed rates of population increase by 56.9 and $23.8 \%$, respectively during the first 3 days of refrigerator storage, then showed a reduction by 29.7 and $42.5 \%$, respectively. Enterococci and yeasts counts showed rates of population increase by 40.2 and $107.03 \%$, respectively during the first 5 days of refrigerator storage, then showed a rate of decrease by 11.6 and $2.87 \%$, respectively afterwards. These results indicate that all microbial counts, significantly increased ( $\mathrm{p}<$ 0.05 ) when stored at refrigerator temperature for 7 days. Lactic acid bacteria and fungi counts showed rates of increase by 42.5 and $37.7 \%$, respectively during the first 4 days of refrigerator storage, then non-significantly decreased afterwards. Similar results were found by Francis and O'Beirne (2001) who found that the populations of E. coli O157:H7 on coleslaw mix $(80 \%$ shredded cabbage, $20 \%$ shredded carrot) stored at $8^{\circ} \mathrm{C}$ had increased by approximately $1.5 \log$ cycles by day 5 , then declined by 1 to 2 log cycles, depending on the strain. Populations of E. coli O157:H7 decreased at $4^{\circ} \mathrm{C}$ by 1 to $1.5 \log$ cycles, but viable cells were still detected at the end of the storage period. Abdul-Raouf et al. (1993) reported that 
populations of E. coli $\mathrm{O} 157: \mathrm{H} 7$ numbers on shredded carrots $\left(12^{\circ} \mathrm{C}\right)$ increased during initial days of storage and subsequently declined on extended storage. Arias et al. (2001) stated that

Table 3. Changes in vegetable salad microbial popualtion ${ }^{\text {a }}$ during refrigerator storage for $\mathbf{7}$ days

\begin{tabular}{|c|c|c|c|c|c|c|c|c|}
\hline Microbial count & 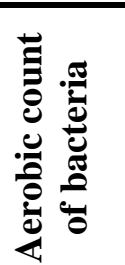 & هِ & 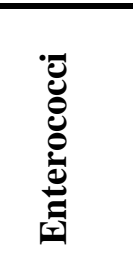 & 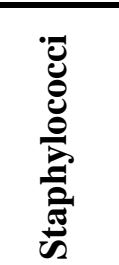 & 苞 & 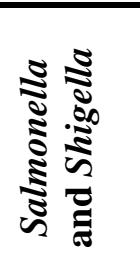 & 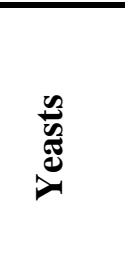 & 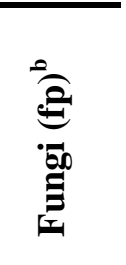 \\
\hline$\overline{\text { Zero }}$ & $5.06 \mathrm{e}$ & $5.81 \mathrm{~d}$ & $5.62 \mathrm{c}$ & $3.69 \mathrm{a}$ & $3.23 \mathrm{~cd}$ & $3.40 \mathrm{~b}$ & $3.41 \mathrm{e}$ & $3.34 \mathrm{c}$ \\
\hline 1 & $6.38 \mathrm{c}$ & 6.33 c & $6.95 \mathrm{~b}$ & $3.81 \mathrm{a}$ & 3.56 bc & $3.64 \mathrm{ab}$ & $3.76 \mathrm{~d}$ & $3.63 \mathrm{c}$ \\
\hline 2 & $7.12 \mathrm{~b}$ & $7.09 \mathrm{~b}$ & $7.00 \mathrm{~b}$ & $3.30 \mathrm{~b}$ & $3.91 \mathrm{ab}$ & $3.85 \mathrm{a}$ & 5.59 c & $4.20 \mathrm{~b}$ \\
\hline 3 & $7.94 \mathrm{a}$ & $8.07 \mathrm{a}$ & $7.66 \mathrm{a}$ & $3.08 \mathrm{~b}$ & $4.00 \mathrm{a}$ & $2.90 \mathrm{c}$ & $6.41 \mathrm{~b}$ & $4.48 \mathrm{ab}$ \\
\hline 4 & $7.78 \mathrm{a}$ & $8.28 \mathrm{a}$ & $7.76 \mathrm{a}$ & $3.00 \mathrm{~b}$ & $3.82 \mathrm{ab}$ & $2.80 \mathrm{c}$ & $6.90 \mathrm{a}$ & $4.60 \mathrm{a}$ \\
\hline 5 & $7.31 \mathrm{~b}$ & 8.15 a & $7.88 \mathrm{a}$ & $0.00 \mathrm{c}$ & $3.11 \mathrm{~d}$ & $2.70 \mathrm{c}$ & $7.06 \mathrm{a}$ & $4.23 \mathrm{~b}$ \\
\hline 6 & $7.25 \mathrm{~b}$ & $8.13 \mathrm{a}$ & $7.56 \mathrm{a}$ & $0.00 \mathrm{c}$ & $2.95 \mathrm{~d}$ & $2.60 \mathrm{c}$ & $6.95 \mathrm{a}$ & $4.20 \mathrm{~b}$ \\
\hline 7 & $5.58 \mathrm{~d}$ & $8.10 \mathrm{a}$ & $7.00 \mathrm{~b}$ & $0.00 \mathrm{c}$ & $2.30 \mathrm{e}$ & $2.30 \mathrm{~d}$ & $6.86 \mathrm{a}$ & $4.18 \mathrm{~b}$ \\
\hline
\end{tabular}

a- Numbers (log cfu/g) are mean values of three replicates.

b- fp: Fungal propagules.

populations of $E$. coli O157: H7, significantly increased on chopped cabbage after $48 \mathrm{hr}$., of storage at $6^{\circ} \mathrm{C}$, followed by significant $(\mathrm{p}<0.05)$ decrease after $72 \mathrm{hr}$., cabbage initially containing a large inoculum $\left(10^{8} \mathrm{cfu} / \mathrm{g}\right)$. On the other hand, populations on cabbage stored at $12^{\circ} \mathrm{C}$, significantly increased within $72 \mathrm{hr}$. On cabbage, the count of E. coli O157:H7 ranged from $2.7 \times 10^{3}-4.0 \times 10^{2} \mathrm{cfu} / \mathrm{g}$ and the $\mathrm{pH} 7.09$ 5.72 at $5^{\circ} \mathrm{C}$, while at $28^{\circ} \mathrm{C}$ the count was $2.5 \times 10^{3}-1.0 \times 10^{2} \mathrm{cfu} / \mathrm{g}$ and the $\mathrm{pH} 7.09-4.15$. The count of E. coli $\mathrm{O} 157: \mathrm{H} 7$ on lettuce at $5^{\circ} \mathrm{C}$ was in the range of $3.6 \times 10^{3}-5.0 \times 10^{2} \mathrm{cfu} / \mathrm{g}$ and the $\mathrm{pH}$ decreased from 7.11 to 5.66 . At $28^{\circ} \mathrm{C}$, the count was $3.9 \times 10^{3}-1.0 \times 10^{2} \mathrm{cfu} / \mathrm{g}$ and the $\mathrm{pH}$ decreased from 7.11 to 4.06 .

The decreased numbers of $E$. coli O157:H7 in stored vegetable salad may be due to the effect of decreasing $\mathrm{pH}$ during storage and competition with other microorganisms (Uzeh and Adepoju, 2013).

Salmonella and Shigella counts showed a rate of increase by $13.2 \%$ after 2 days of refrigerator storage, then showed a rate of decrease by $40.25 \%$ by the end of storage period. Staphylococci counts showed a rate of increase by $3.25 \%$ after the first day of storage, then significantly decreased afterwards. These results indicate that most microbial groups consistently increased until days 3-5, then slightly decreased until day 7.

\section{Effect of refrigerator storage on couscous}

The effect of refrigerator storage on microbial load of couscous sample is shown in Table 4 . The results showed that total bacterial count increased by $58.06 \%$ after 6 days of refrigerator storage, then decreased afterwards. Enterococci, Staphylococci, and Salmonella and Shigella counts showed a rate of increase by 84.1, 71.65 and $66.49 \%$ respectively, after 6 days of refrigerator storage, then decreased afterwards. The counts of lactic acid bacteria and yeasts significantly increased $(\mathrm{p}<0.05)$ during the first three days, then stayed with mostly non-significant changes throughout the remaning days. Fungi counts showed a rate of increase by $5.42 \log$ after 8 days of refrigerator storage, then decreased in day 9. Coliform counts showed a rate of increase by $41.35 \%$ after 5 days of refrigerator storage, then showed a rate of reduction by $19.12 \%$ afterwards 
comparing with the count at the $5^{\text {th }}$ day. These results indicate that the most microbial groups consistently increased until days 6-8, then slightly decreased until day 9 . 
Table 4. Changes in couscous microbial popualtion ${ }^{\mathrm{a}}$ during refrigerator storage for 9 days

\begin{tabular}{|c|c|c|c|c|c|c|c|c|}
\hline Microbial count & 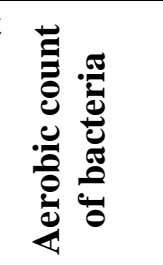 & 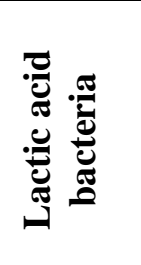 & 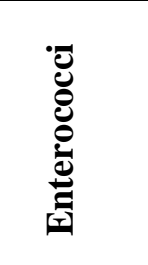 & 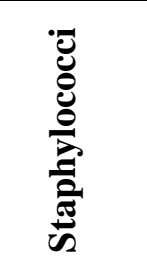 & $\underset{0}{\stackrel{0}{0}}$ & 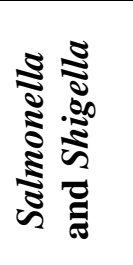 & 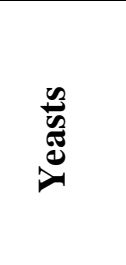 & 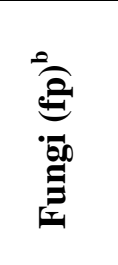 \\
\hline Zero & $6.20 \mathrm{~g}$ & $4.83 \mathrm{f}$ & $4.03 \mathrm{~g}$ & $5.15 \mathrm{~g}$ & $5.03 \mathrm{f}$ & $5.73 \mathrm{e}$ & $3.64 \mathrm{f}$ & $0.00 \mathrm{e}$ \\
\hline 1 & $7.11 \mathrm{f}$ & $5.71 \mathrm{e}$ & $4.67 \mathrm{f}$ & $6.06 \mathrm{f}$ & $5.48 \mathrm{e}$ & $6.49 \mathrm{~d}$ & 4.59 e & $0.00 \mathrm{e}$ \\
\hline 2 & 8.12 e & $7.12 \mathrm{~d}$ & 5.59 e & $6.74 \mathrm{e}$ & $6.30 \mathrm{~d}$ & $7.60 \mathrm{c}$ & $5.10 \mathrm{~d}$ & $0.00 \mathrm{e}$ \\
\hline 3 & $9.12 \mathrm{~cd}$ & $7.81 \mathrm{c}$ & $7.05 \mathrm{~b}$ & $7.42 \mathrm{~d}$ & $6.99 \mathrm{ab}$ & $8.53 \mathrm{~b}$ & $6.01 \mathrm{c}$ & $0.00 \mathrm{e}$ \\
\hline 4 & 9.24 bcd & 8.00 bc & $7.20 \mathrm{ab}$ & $7.64 \mathrm{~cd}$ & $7.34 \mathrm{a}$ & 8.72 b & $6.03 \mathrm{c}$ & $2.78 \mathrm{~d}$ \\
\hline 5 & 9.29 abc & $8.18 \mathrm{~b}$ & $7.23 \mathrm{ab}$ & $7.93 \mathrm{c}$ & $7.11 \mathrm{a}$ & $9.53 \mathrm{a}$ & $6.19 \mathrm{c}$ & $4.03 \mathrm{c}$ \\
\hline 6 & $9.62 \mathrm{a}$ & $8.71 \mathrm{a}$ & $7.42 \mathrm{a}$ & $8.84 \mathrm{a}$ & 6.67 bc & $9.54 \mathrm{a}$ & $6.20 \mathrm{c}$ & $4.28 \mathrm{c}$ \\
\hline 7 & $9.57 \mathrm{ab}$ & $8.74 \mathrm{a}$ & 6.91 bc & $8.77 \mathrm{a}$ & $6.53 \mathrm{~cd}$ & $8.67 \mathrm{~b}$ & $6.60 \mathrm{~b}$ & $4.88 \mathrm{~b}$ \\
\hline 8 & 9.29 abc & $8.81 \mathrm{a}$ & $6.62 \mathrm{~cd}$ & $8.31 \mathrm{~b}$ & $5.81 \mathrm{e}$ & $8.66 \mathrm{~b}$ & $6.75 \mathrm{~b}$ & $5.42 \mathrm{a}$ \\
\hline 9 & $8.89 \mathrm{~d}$ & $8.84 \mathrm{a}$ & $6.43 \mathrm{~d}$ & $7.86 \mathrm{c}$ & 5.75 e & 8.65 b & 7.29 a & $4.67 \mathrm{~b}$ \\
\hline
\end{tabular}

a- Numbers (log cfu/g) are mean values of three replicates. $\quad$ b- fp: Fungal propagules.

\section{Effect of storage at ambient temperature on koshari}

Data in Table 5 show the effect of room temperature storage on microbial load of Koshari samples. Total bacterial count, lactic acid bacteria, enterococci, coliforms, Salmonella and Shigella and fungi counts showed the rate of increase reaching 39.49, 270.9, 130.2, 145.7, 620 and $43.47 \%$, respectively, after $24 \mathrm{hr}$. Staphylococci counts showed a rate of increase by $50.06 \%$ after $12 \mathrm{hr}$., of room temperature storage, then decreased after 24 hours. No count of yeasts was detected during the 24 hours of storage at room temperature. The counts of fungi showed the lowest rate of increase by $43.47 \%$, while lactic acid bacteria showed the highest rate of increase by $270.86 \%$. Other than yeasts, Salmonella and Shigella showed the lowest counts at zero time, while the total count of bacteria showed the highest numbers at zero time as expected. These results indicate that all microbial counts significantly increased $(\mathrm{p}<0.05)$ when stored at room temperature for 24 hours.

The numbers of total counts in this study is much higher than those reported in the study of
Ali et al. (2008) who found that the bacterial load counted in the cooked rice kept at room temperature $\left(30 \pm 2^{\circ} \mathrm{C}\right)$ for 24 hours was about $4.2 \times 10^{4} \mathrm{cfu} / \mathrm{g}$. This may be due to the different in preparation conditions of the food since the rice prepared in their study seems to be prepared at home or in the lab, in much better conditions compared to the public restaurants. Also, the zero time in the current study is not the zero time for koshari preparation, but is most likely several hours after preparation. Furthermore, the chemical composition of koshari contains different variety of nutrients including proteins (from lentil and pasta) and more fats and moisture, unlike rice. Such versatile composition of koshari would make it better medium for microbial growth and proliferation.

\section{Effect of storage at ambient temperature on vegetable salad}

Data in Table 6 show the effect of room temperature storage $\left(22 \pm 2^{\circ} \mathrm{C}\right)$ on microbial load of vegetable salad sample. The microbial counts consistently increased and significantly ( $\mathrm{p}<$ 0.05 ) during the storage of vegetable salad at room temperature for 36 hours. Total bacterial 
Table 5. Changes in koshari microbial popualtion ${ }^{\mathrm{a}}$ during storage at ambient temperature for 24 hours

\begin{tabular}{|c|c|c|c|c|c|c|c|c|}
\hline Microbial count & 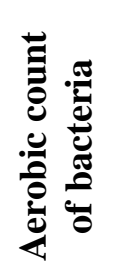 & هَّ & 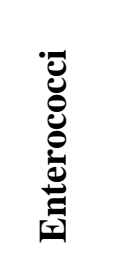 & 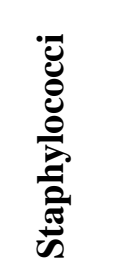 & : & 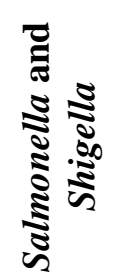 & 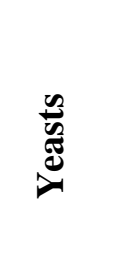 & 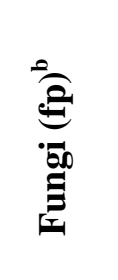 \\
\hline$\overline{\text { Zero }}$ & $6.33 \mathrm{~b}$ & $2.30 \mathrm{c}$ & $3.30 \mathrm{c}$ & $3.75 c$ & $3.15 \mathrm{~b}$ & $0.00 \mathrm{c}$ & $0.00 \mathrm{a}$ & $2.30 \mathrm{~b}$ \\
\hline 12 & $9.14 \mathrm{a}$ & $8.01 \mathrm{~b}$ & $6.74 \mathrm{~b}$ & $7.51 \mathrm{a}$ & 7.68 a & $4.82 \mathrm{~b}$ & $0.00 \mathrm{a}$ & $3.30 \mathrm{a}$ \\
\hline 24 & 8.83 a & $8.53 \mathrm{a}$ & $7.60 \mathrm{a}$ & $6.64 \mathrm{~b}$ & $7.74 \mathrm{a}$ & 6.20 a & $0.00 \mathrm{a}$ & $3.30 \mathrm{a}$ \\
\hline
\end{tabular}

a- Numbers (log cfu/g) are mean values of three replicates. $\quad$ b- fp: Fungal propagules.

Table 6. Changes in vegetable salad microbial popualtion ${ }^{a}$ during storage at ambient temperature for 36 hours

\begin{tabular}{|c|c|c|c|c|c|c|c|c|}
\hline Storage time (hour) & 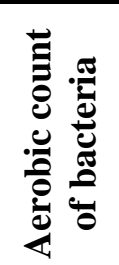 & د & 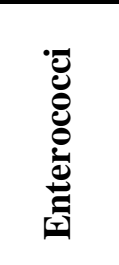 & 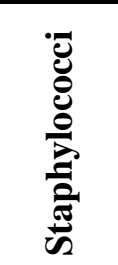 & 苞 & 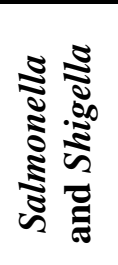 & 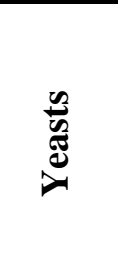 & 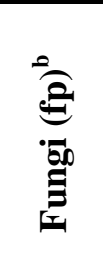 \\
\hline$\overline{\text { Zero }}$ & $6.15 \mathrm{c}$ & $5.15 \mathrm{~d}$ & $2.00 \mathrm{~d}$ & $3.87 \mathrm{c}$ & $4.74 \mathrm{~d}$ & $4.65 \mathrm{c}$ & $4.64 \mathrm{~d}$ & $0.00 \mathrm{a}$ \\
\hline 12 & $8.34 \mathrm{~b}$ & 7.99 c & $5.99 \mathrm{c}$ & $6.48 \mathrm{~b}$ & $6.9 \mathrm{c}$ & $6.09 \mathrm{~b}$ & $5.14 \mathrm{c}$ & $0.00 \mathrm{a}$ \\
\hline 24 & $8.67 \mathrm{~b}$ & $8.96 \mathrm{~b}$ & $6.94 \mathrm{~b}$ & $6.79 \mathrm{~b}$ & $7.47 \mathrm{~b}$ & $7.33 \mathrm{a}$ & $6.62 \mathrm{~b}$ & $0.00 \mathrm{a}$ \\
\hline 36 & $9.70 \mathrm{a}$ & $9.60 \mathrm{a}$ & $8.18 \mathrm{a}$ & $7.82 \mathrm{a}$ & $7.85 \mathrm{a}$ & $7.68 \mathrm{a}$ & $9.22 \mathrm{a}$ & $0.00 \mathrm{a}$ \\
\hline
\end{tabular}

a- Numbers (log cfu/g) are mean values of three replicates. b- fp: Fungal propagules.

count, lactic acid bacteria, enterococci, staphylococci, coliforms, Salmonella and Shigella and yeasts counts showed an increasing percentages of 57.7, 86.4, 309, 102.06, 65.6, 65.2 and $98.7 \%$, respectively. Similar results were obtained by Francis and O'Beirne (2001) who found that the populations of viable E. coli O157 : H7, significantly increased on lettuce stored at $21^{\circ} \mathrm{C}$. This may be due to the effect of decrease in $\mathrm{pH}$ of the vegetables during storage and competition with other microorganisms present, including lactic bacteria. On the other hand, the current results are contradicts with the findings of Faith et al. (1997) who found reductions in bacterial number in pepperoni by 2-4 log cfu/g when stored at $21^{\circ} \mathrm{C}$ for 14 days.

No counts of fungi could be detected during the 36 hours of room temperature $\left(22 \pm 2{ }^{\circ} \mathrm{C}\right)$ storage. Moulds are less important in minimally processed vegetables due to the intrinsic properties such as a slightly acid to neutral $\mathrm{pH}$ favouring bacteria and yeasts which will overgrow moulds (Magnuson et al., 1990; King et al., 1991; Lund, 1992; Moss, 1999; Gimenez et al., 2003; Tournas, 2005). The counts of Salmonella and Shigella showed the lowest rate of increase by $65.2 \%$, while enterococci showed the highest rate of increase by $309 \%$. Enterococci showed the lowest numbers at zero time, while the total count of bacteria showed the highest numbers at zero time.

\section{Effect of storage at ambient temperature on couscous}

Data in Table 7 show the effect of room temperature storage on microbial counts of couscous sample. Total bacterial count, lactic acid bacteria, Enterococci, Staphylococci, coliforms, 
Table 7. Changes in couscous microbial popualtion ${ }^{\mathrm{a}}$ during storage at ambient temperature for 24 hours

\begin{tabular}{|c|c|c|c|c|c|c|c|c|}
\hline Microbial count & 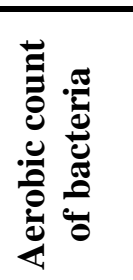 & 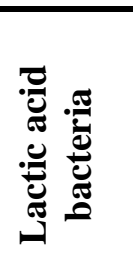 & 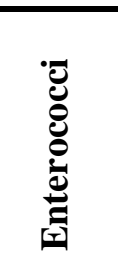 & 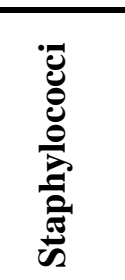 & : & 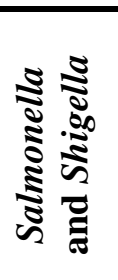 & $\frac{n}{\tilde{g}}$ & 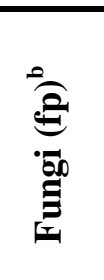 \\
\hline$\overline{\text { Zero }}$ & $4.03 \mathrm{c}$ & $2.15 \mathrm{c}$ & $3.98 \mathrm{~b}$ & $4.84 \mathrm{c}$ & $0.00 \mathrm{c}$ & $0.00 \mathrm{c}$ & $0.00 \mathrm{~b}$ & $0.00 \mathrm{a}$ \\
\hline 12 & $7.26 \mathrm{~b}$ & $5.90 \mathrm{~b}$ & $7.03 \mathrm{a}$ & $7.46 \mathrm{~b}$ & $6.14 \mathrm{~b}$ & $4.70 \mathrm{~b}$ & $4.94 \mathrm{a}$ & $0.00 \mathrm{a}$ \\
\hline 24 & $8.12 \mathrm{a}$ & $6.60 \mathrm{a}$ & $7.18 \mathrm{a}$ & $8.48 \mathrm{a}$ & $7.34 \mathrm{a}$ & $6.62 \mathrm{a}$ & $5.20 \mathrm{a}$ & $0.00 \mathrm{a}$ \\
\hline
\end{tabular}

a- Numbers (log cfu/g) are mean values of three replicates.

b- fp: Fungal propagules.

Salmonella and Shigella and yeasts counts showed a rate of increase by 101.48, 206.97, 80.4, 75.4, 734, 662and 520 1\%, respectively. No counts of fungi were detected after 24 hours of room temperature storage. The counts of enterococci showed the lowest rate of increase by $320 \%$, while coliforms showed the highest rate of increase by $734 \%$. The results indicated that all microbial counts significantly increased $(p<0.05)$ when stored at room temperature for 24 hours.

The consistent microbial increase for all groups under different conditions had led to natural changes in the koshari shown as deterioration in appearance and unpleasant smell.

In view of the obtained results, it could be concluded that it is higher recommended to follow routine inspections and training of vendors to improve the microbiological quality of food products.

\section{REFERENCE}

Abdul- Raouf, U.M., L.R. Beuchat and M.S. Ammar (1993). Survival and growth of $E$. coli $\mathrm{O} 157$ : H7 on salad vegetables. Appl. Environ Microbiol., 59: 1999-2006.

Ali, M.A., S.M.K. Hasan and M.N. Islam (2008). Study on the period of acceptability of cooked rice. J. Bangladesh Agric. Univ., 6 (2): 401-408.
Angelidis, A.S., E.N. Chronis, D.K. Papageorgiou, I.I. Kazakis, K.C. Arsenoglou and G.A. Stathopoulos (2006). Non-lactic acid contaminating flora in ready-to-eat foods: A potential food-quality index. Food Microbiol., $23: 95-100$.

Arias, M.L., R. Monge-Rojas, C. Chaves and F. Antillon (2001). Effect of storage temperatures on growth and survival of Escherichia coli O157 : H7 inoculated in foods from a neotropical environment. Int. J. Trop. Biol. and Cons., 49: 517-524

Baird-Parker, A.C. and E. Davenport (1965). The effect of recovery medium on the isolation of $S$. aureus after heat treatment and after the storage of frozen or dried cells. J. Appl. Bacteriol., 28 : 390-402.

Beuchat, L.R. and J.H. Ryu (1997). Produce handling and processing practices. Emerging Inf. Dis., 3 : 459-465.

Brandl, A.M. (2006). Fitness of human enteric pathogens on plants and implications for food safety. Ann. Rev. Phytopathol., 44:367-392.

Christison, C.A., D. Lindsay and A. Vaon holy (2008). Microbiological survey of ready to eat foods and associated preparation surfaces in retail delicatessens, Johannesburry, South Africa. Food Control, 19:727-733.

De-Man, J.C., M. Rogosa and M.E. Sharp (1960). Medium of lactobacilli. J. Appl. Bacterial., 23: 130 - 135. 
Difco (1989). Difco Manual of Dehydrated Culture Media and Reagents for Microbiological and Clinical Laboratories Products. Ninth Edition, difco laboratories, Detriot Michgan, USA.

Duncan, D.B. (1955). Multiple range and multiple F test. Biometrics, 11:1-42.

Faith, N.G., N. Parniere, T. Larson, T. Lorang and J. Luchansky (1997). Viability of Escherichia coli O157: H7 in pepperoni during the manufacture of sticks and the subsequent storage of slices at 21, 4 and -20 degrees $\mathrm{C}$ under air, vacuum and $\mathrm{CO}_{2}$. Int. J. Food Microbiol., 37: 47-54.

Fang, T.J., Q.K. Wei, C.W. Liao, M.J. Hung and T.H. Wang (2003). Microbiological quality of $18^{\mathrm{O}} \mathrm{C}$ ready-to-eat food products sold in Taiwan. Int. J. of Food Microbiol., 80 (3): 241-250.

FEHD (2007). Food and Environmental Hygiene Department, Microbiological guidelines for ready-to-eat food.

Francis, G.A. and D. O’Beirne (2001). Effects of vegetable type, package atmosphere and storage temperature on growth and survival of Escherichia coli $0157: \mathrm{H7}$ and Listeria monocytogenes. J. Industrial Microbiol. and Biotechnol., 27: 111-116.

Francis, J., C. Thomas and D. O’Beirne (1999). The microbiological safety of minimally processed vegetables. Int. J. Food Sci. Technol., 34 : 1-22.

Franz, E. and A.H.C. Van Bruggen (2008). Ecology of E. coli O157:H7 and Salmonella enterica in the primary vegetable production chain. Crit. Rev. Microbiol., 34, 143-161.

Frazier, W.C. and D.C. Westhoff (1995). Food Microbiology. $4^{\text {th }}$ Ed. and $28^{\text {th }}$ reprint 2007. Tata McGraw-Hill Pub. Co. Ltd. New Delhi., $54: 508$.

Fröder, H., C.G. Martins, K.I. De Souza, M. Landgraf, B. Franco and M.T. Destro (2007). Minimally processed vegetable salads, microbial quality evaluation. J. Food Prot., 70: 1277-1280.

Gibbons, I.S., A. Adesiyun, N. Seepersadsingh and S. Rahaman (2006). Investigation for possible source (s) of contamination of ready-to-eat meat products with Listeria spp. and other pathogens in a meat processing plant in Trinidad. Food Microbiol., 23: 359366.

Gilbreth, S.E., J.E. Call, F.M. Wallace, V.N. Scott, Y. Chen and J.B. Luchansky (2005). Relatedness of Listeria monocytogenes isolates recovered from selected ready-to-eat foods and listeriosis patients in the United States. Appl. and Environ. Microbiol., 71 : 8115-8122.

Gimenez, M., C. Olarte, S. Sanz, C. Lomas, J.F. Ech'avarri and F. Ayala (2003). Relation between spoilage and microbiological quality in minimally processed artichoke packaged with different films. Food Microbiol., 20 : 231-242.

Gitahi, M.G., J. Wangoh and P.M.K. Niage (2012). Microbial safety of street food in industrial area, Nairbi. Research J. Microbiol., 7 (6): 297-308.

Hanoshiro, A., M. Morita, G. Matte, M. Matte and E. Torres (2004). Microbiological quality of selected foods from restricted areas of Sao Pau-lo City, Brazil. Food Control, 16: 439-440.

Harrigen, W.F. and E. Mccance-Margart (1976). Laboratory Methods in Food and Dairy Microbiology. Academic Press, London, 1 115.

Hausler, W.J. (1972). Strandard methods for examination dairy products. $13^{\text {th }}$ Ed. Washington, D.C.; Ame. Public Health Associated.

Heaton, J.C. and K. Jones (2007). Microbial examination of fruit and vegetables and the behaviour of enteropathogens in the phyllosphere, a review. J. Appl. Microbiol., 104 : 613-626.

King, A.D., J.A. Magnuson, T. Torok and N. Goodman (1991). Microbial flora and storage quality of partially processed lettuce. J. Food Sci., 56:459-461.

Kreger-van Rij, N.J.W. (1984). The yeasts, a taxonomic study3. Aufl. Groningen. The Netherlands. Elservir Science puplishers B. V. Amesterdam. 
Lund, B.M. (1992). Ecosystems in vegetable foods. J. Appl. Bacteriol., 73 : S115-S126.

Magnuson, J.A., A.D. King and T. Torok (1990). Microflora of partially processed lettuce. Appl. Environ. Microbiol., 56 : 3851 -3854 .

Mensah, P., D. Yebaah-Manu, K. Owusu-Darjo and A. Albordey (2002). Streets foods in accra, Ghana: How safe are they? Bull. World Health Organ., 80 : 546 - 554.

Moss, M.O. (1999). Spoilage problems/ problems caused by fungi. In: Robinson, R.K., Batt, C.A., Patel, P.D. (Eds.), Encyclopedia of Food Microbiology. Acad. Press, London.

Nester, E.W., D.G. Anderson, C.E. Roberts, N.N. Pearsa and M.T. Nester (2001). Microbiology: A human perspective. $3^{\text {rd }}$ Ed., McGraw-Hill, New York, ISBN: 0072318783, 815-816.

Pavan da Silva, S.R., S.E. Frizzo Verdin, D.C. Pereira, A.M. Schatkoski, M.B. Rott and G. Corção (2007). Microbiological quality of minimally processed vegetables sold in Porto Alegre, Brazil. Braz. J. Microbiol., 38: 594598.

Pianetti, A., L. Sabatini, B. Citterio, L. Pierfelici, P. Ninfali and F. Bruscolini (2008). Changes in microbial populations in ready-to-eat vegetable salads during shelflife. Ital. J. Food Sci., 20 : 245-254.

SAS (1998). (Statistical Analysis System) SAS Inst., Inc., Cary, Nc.

Sinigaglia, M., M. Albenzio and M.R. Corbo (1999). Influence of process operations on shelf-life and microbial population of freshcut vegetables. J. Ind. Microbiol. Biotechnol., 23 : 484-488.

Tournas, V.H. (2005). Moulds and yeasts in fresh and minimally processed vegetables and sprouts. Int. J. Food Microbiol., 99 : 7177.

Umoh, V.J and M.B. Odobab (1999). Safety and quality evaluation of street foods sold in Zaria, Nigeria. Food control, 10 : 9-14.

USFDA (2009). United States Food and Drug Administration. Food Code.

Uzeh, R.E. and A. Adepoju (2013). Incidence and survival of Escherichia coli O157:H7 and Listeria monocytogenes on salad vegetables. Int. Food Res. J., 20(4): 19211925.

Wojcik-Stopczynska, B. (2004). Microbiological quality of minimally processed vegetable salads. Rocz. Panstw. Zakl. Hig., 55:139-145. 


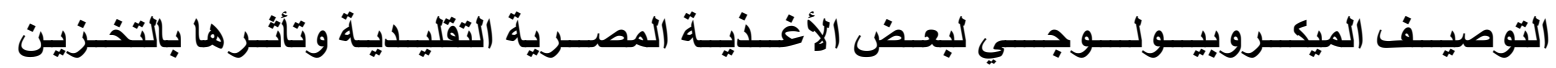

$$
\begin{aligned}
& \text { آية محمد إبراهيم فراج - ناهد أمين الوفائي - هويدا محمد لبيب عبد الباسط ـ محمد إبراهيم حجازي }
\end{aligned}
$$

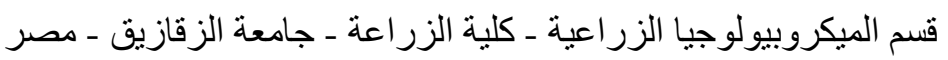

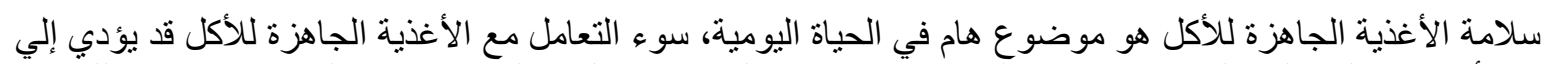

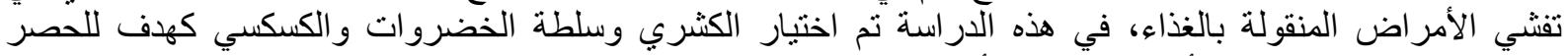

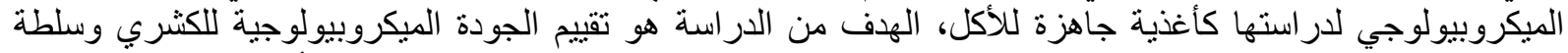

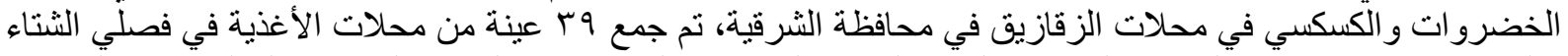

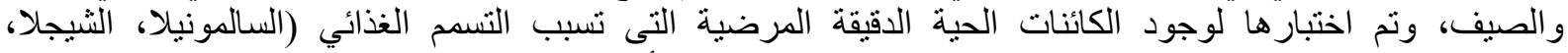

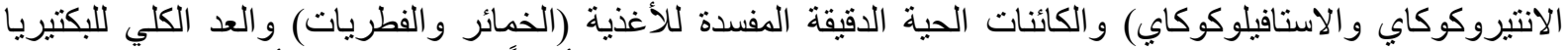

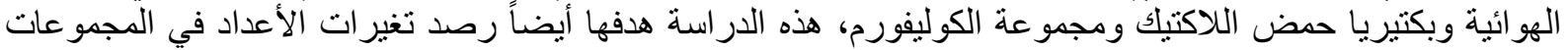

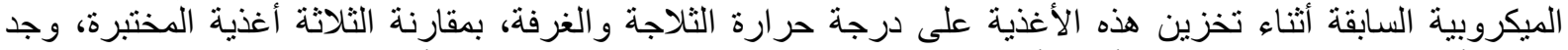

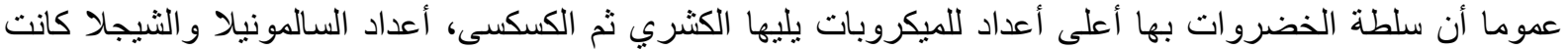

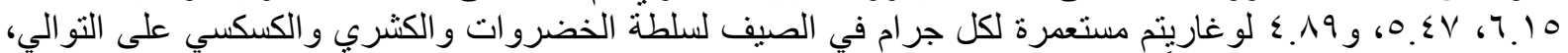

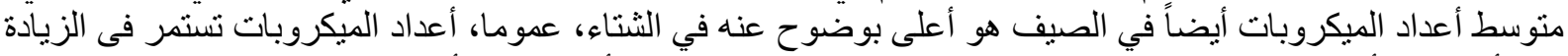

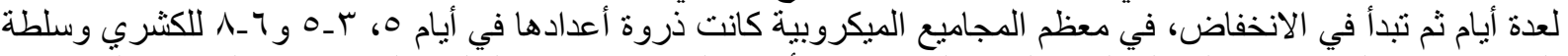

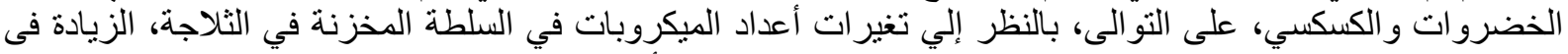

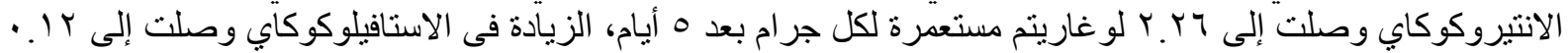

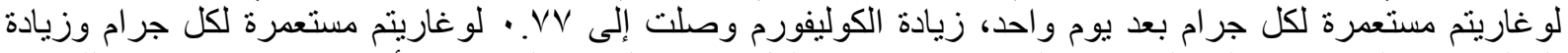

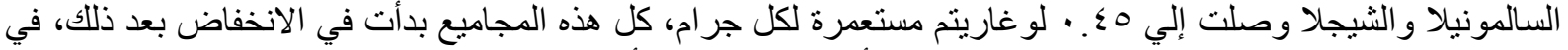

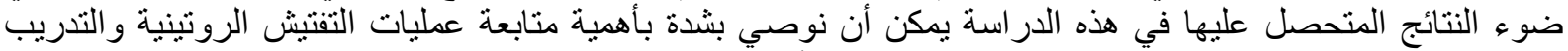
للباعة والمتعاملين مع الغذاء لتحسين مستويات الجودة في الأغذية الثعبية.

أستاذ الميكروبيولوجيا - كلية الزر اعة بمشتهر - جامعة بنها.

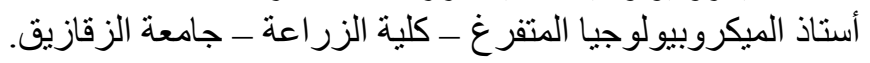

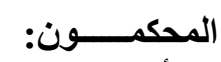

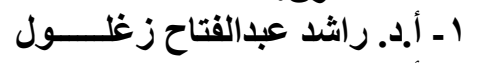
r أ أ.د. جمال الدين عصطفى محمد 